\title{
Aa. Vv., «Bulletin des Amis d'André Gide »
}

\section{Emanuele Kanceff}

\section{Q OpenEdition}

\section{Journals}

\section{Edizione digitale}

URL: http://journals.openedition.org/studifrancesi/35096

DOI: 10.4000/studifrancesi.35096

ISSN: 2421-5856

\section{Editore}

Rosenberg \& Sellier

\section{Edizione cartacea}

Data di pubblicazione: 1 novembre 2005

Paginazione: 445-446

ISSN: 0039-2944

\section{Notizia bibliografica digitale}

Emanuele Kanceff, «Aa. VV., «Bulletin des Amis d'André Gide »», Studi Francesi [Online], 146 (XLIX | II) | 2005, online dal 30 novembre 2015, consultato il 19 avril 2021. URL: http://journals.openedition.org/ studifrancesi/35096 ; DOI: https://doi.org/10.4000/studifrancesi.35096

\section{Questo documento è stato generato automaticamente il 19 avril 2021.}

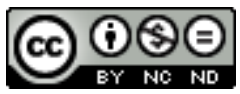

Studi Francesi è distribuita con Licenza Creative Commons Attribuzione - Non commerciale - Non opere derivate 4.0 Internazionale. 


\title{
Aa. Vv., «Bulletin des Amis d'André Gide »
}

\author{
Emanuele Kanceff
}

\section{NOTIZIA}

«Bulletin des Amis d'André Gide », trente-sixième année, vol. XXXII, n. 141, avril 2004, $140 \mathrm{pp}$.

1 Sempre vitale e piena di preziosi contenuti, la rivista della Associazione degli Amici di André Gide continua a fornire uno strumento utilissimo per gli studi. Nell'impossibilità di analizzare i singoli studi in questa sede, diamo, come di consueto, i contenuti del «Bulletin» n. 141: Thomas CAZENTRE: Les comédiens sans le savoir: l'inconscient dramatique dans «La Porte étroite». - Anton ALBLAS: L'œuvre instantanée: le Journal d'André Gide. III. La genèse du Journal (suite). - Claude FOUCART: Eduard Wechssler et André Gide à Berlin en 1928. Robert LEVESQUE: Journal inédit (novembre-décembre 1944). - Les Dossiers de presse des livres d'André Gide: Interviews imaginaires (Émilie NOULET), Robert (Benjamin CRÉMIEUX), Oedipe (Oliver BRACHFELD), La Porte étroite (Paul DERMÉE), Voyage au Congo (Jeanne BERNY), Ainsi soit-il (André rousSEAuX). - Les bons dessous ou l'art du bien vieillir. Compléments au Dossier de presse de L 'Immoraliste (Sainte-Claire, Charles de Spirmont, Marie Fuhrmann, Camill Hoffmann, Julie Speyer), présentés par Tom REISEN. - Lectures gidiennes: Sidonie Rivalin-Padiou, André Gide: à corps défendu [par Jean-Michel wITTMANN]. - Tom CONNER (ed.), André Gide’s Politics [par Frédéric Canovas]. - Chronique bibliographique. 